\title{
Titanium Dioxide Nanoparticles Induce Inhibitory Effects against Planktonic Cells and Biofilms of Human Oral Cavity Isolates of Rothia mucilaginosa, Georgenia sp. and Staphylococcus saprophyticus
}

\author{
Saher Fatima ${ }^{1}$, Khursheed Ali ${ }^{1, *}$, Bilal Ahmed ${ }^{2, *} \mathbb{D}$, Abdulaziz A. Al Kheraif ${ }^{3}$, Asad Syed ${ }^{4}$, \\ Abdallah M. Elgorban ${ }^{4} \mathbb{D}$, Javed Musarrat ${ }^{1}$ and Jintae Lee ${ }^{2}$ \\ 1 Faculty of Agricultural Sciences, Department of Agricultural Microbiology, Aligarh Muslim University, \\ Aligarh 202002, India; saherfatima.amu@gmail.com (S.F.); musarratj1@yahoo.com (J.M.) \\ 2 School of Chemical Engineering, Yeungnam University, Gyeongsan 38541, Korea; jtlee@ynu.ac.kr \\ 3 Dental Health Department, College of Applied Medical Sciences, King Saud University, P.O. Box 10219, \\ Riyadh 11433, Saudi Arabia; aalkhuraif@ksu.edu.sa \\ 4 Department of Botany and Microbiology, College of Science, King Saud University, P.O. Box 2455, \\ Riyadh 11451, Saudi Arabia; assyed@ksu.edu.sa (A.S.); aelgorban@ksu.edu.sa (A.M.E.) \\ * Correspondence: khursheedamu@gmail.com (K.A.); bilal22000858@yu.ac.kr (B.A.)
}

check for updates

Citation: Fatima, S.; Ali, K.; Ahmed, B.; Al Kheraif, A.A.; Syed, A.; Elgorban, A.M.; Musarrat, J.; Lee, J. Titanium Dioxide Nanoparticles Induce Inhibitory Effects against Planktonic Cells and Biofilms of Human Oral Cavity Isolates of Rothia mucilaginosa, Georgenia sp. and Staphylococcus saprophyticus. Pharmaceutics 2021, 13, 1564. https://doi.org/10.3390/ pharmaceutics13101564

Academic Editor: Clive Prestidge

Received: 22 August 2021

Accepted: 23 September 2021

Published: 26 September 2021

Publisher's Note: MDPI stays neutral with regard to jurisdictional claims in published maps and institutional affiliations.

Copyright: (c) 2021 by the authors. Licensee MDPI, Basel, Switzerland. This article is an open access article distributed under the terms and conditions of the Creative Commons Attribution (CC BY) license (https:// creativecommons.org/licenses/by/ $4.0 /)$.

\begin{abstract}
Multi-drug resistant (MDR) bacterial cells embedded in biofilm matrices can lead to the development of chronic cariogenesis. Here, we isolated and identified three Gram-positive MDR oral cocci, (1) SJM-04, (2) SJM-38, and (3) SJM-65, and characterized them morphologically, biochemically, and by 16S rRNA gene-based phylogenetic analysis as Georgenia sp., Staphylococcus saprophyticus, and Rothia mucilaginosa, respectively. These three oral isolates exhibited antibiotic-resistance against nalidixic acid, tetracycline, cefuroxime, methicillin, and ceftazidime. Furthermore, these Gram positive MDR oral cocci showed significant $(p<0.05)$ variations in their biofilm forming ability under different physicochemical conditions, that is, at temperatures of 28,30 , and $42{ }^{\circ} \mathrm{C}, \mathrm{pH}$ of 6.4, 7.4, and 8.4, and $\mathrm{NaCl}$ concentrations from 200 to $1000 \mu \mathrm{g} / \mathrm{mL}$. Exposure of oral isolates to $\mathrm{TiO}_{2} \mathrm{NPs}(14.7 \mathrm{~nm})$ significantly $(p<0.05)$ reduced planktonic cell viability and biofilm formation in a concentration-dependent manner, which was confirmed by observing biofilm architecture by scanning electron microscopy (SEM) and optical microscopy. Overall, these results have important implications for the use of tetragonal anatase phase $\mathrm{TiO}_{2} \mathrm{NPs}$ (size range 5-25 nm, crystalline size $13.7 \mathrm{~nm}$, and spherical shape) as an oral antibiofilm agent against Gram positive cocci infections. We suggest that $\mathrm{TiO}_{2} \mathrm{NPs}$ pave the way for further applications in oral mouthwash formulations and antibiofilm dental coatings.
\end{abstract}

Keywords: oral bacteria; Rothia mucilaginosa; $\mathrm{TiO}_{2} \mathrm{NPs}$; biofilm inhibition

\section{Introduction}

The enormously rich and complex salivary environment of the human oral cavity provides a uniquely structured habitat for a wide variety of commensal (aerobic/anaerobic) microorganisms, and more than an estimated 700 species [1] colonize the oral cavity and form biofilms to ensure their long-term survival. Moreover, notorious biofilm persisters, including streptococci and lactobacilli, live as mutual symbionts within biofilms [2]. Furthermore, it has often been speculated that oral microbiota (bacteria, yeasts, and viruses) promote biofilm formation by producing heterogeneous extracellular polymeric substances (EPS), proteins, and nucleic acids [3]. According to Tawakoli et al. [4], the most dominant oral diseases (caries and periodontitis) are caused by bacterial adherence and subsequent biofilm formation. Multi-layered bacterial biofilm matrices play a vital role in neutralizing the antimicrobial effects of various chemical agents by acquiring drug resistance 
against multiple antibiotics, which is sometimes $>1000$-fold greater than that of planktonic cells $[5,6]$. The metabolism of dietary sucrose/carbohydrates creates a highly acidic microenvironment on tooth surfaces during cariogenic biofilm accumulation, and the resulting tooth surface demineralization leads to periodontal disease and tooth decay, which affect up to $60-90 \%$ of humans [7]. The problems associated with oral biofilms and their clinical management also have significant adverse economic impacts. For example, the cumulative cost of treatments for oral biofilm-related diseases has been estimated to be around USD 81 billion per annum in the United States [8].

The clinical management of biofilm-induced cariogenesis using a variety of metal nanoparticles (NPs) is now being widely explored due to their potential antimicrobial and anti-adhesive characteristics [9-12]. Amongst the metal oxides investigated, nanoscale titanium dioxide $\left(\mathrm{TiO}_{2}\right)$ has a well-established antibacterial effect due to the production of reactive oxygen species (ROS) and cell membrane disrupting/penetrating, glutathione depleting, and toxic oxidative stress augmenting effects $[13,14]$. Furthermore, $\mathrm{TiO}_{2} \mathrm{NPs}$ are normally applied at low concentrations and are widely considered to be bio-compatible [15], though opinions differ regarding inflammation generated by cytokine release [16]. As compared with their micro/bulk-sized counterparts, $\mathrm{TiO}_{2} \mathrm{NPs}$ interact efficiently with a broad range of cell types (e.g., bacteria, fungi, and mammalian cells) due to their greater surface-to-volume ratios [17-19].

Because of its dynamic and open nature and the presence of highly complex mixes of biofilm microflora (due to host susceptibility and poor oral hygiene), the oral cavity has long been regarded as fertile ground for novel persistent biofilms. In the present study, from among ten oral isolates, we selected three Gram positive MDR cocci identified as Georgenia sp. (SJM-04), S. saprophyticus (SJM-38), and R. mucilaginosa (SJM-65) based on their Gram reaction, biochemical make-up, and 16S rRNA-based phylogenetic relatedness. These Gram positive MDR isolates were found resistant to nalidixic acid, tetracycline, cefuroxime, methicillin, and ceftazidime and also showed significant $(p<0.05)$ variations in biofilm formation under different experimental conditions viz., temperatures of 28,30 , or $42{ }^{\circ} \mathrm{C}$, $\mathrm{pH}$ values of 6.4, 7.4, or 8.4, and $\mathrm{NaCl}$ concentrations of 200 to $1000 \mu \mathrm{g} / \mathrm{mL}$. Exposure to $\mathrm{TiO}_{2} \mathrm{NPs}(\cong 14.7 \mathrm{~nm})$ resulted in significant $(p<0.05)$ and concentration-dependent reductions in the viability of planktonic cells and the biofilm formation rates, and these reductions were subsequently confirmed by scanning electron and optical microscopy, respectively. Overall, these results have important implications regarding the use of $\mathrm{TiO}_{2} \mathrm{NPs}$ to eradicate biofilms formed by these three species.

\section{Materials and Methods}

\subsection{Ethics Statement}

Human saliva samples were collected from patients regularly visiting the Outpatient Department (OPD) of the Dr. Ziauddin Ahmad Dental College and Hospital, Aligarh Muslim University, Uttar Pradesh, India for the project CST/372 dated 14 August 2017. The patient's consent was given before sampling. The use of saliva samples for isolation of bacteria was approved by the Internal Ethical Committee, Aligarh Muslim University, Uttar Pradesh, India.

\subsection{Isolation and Culture Conditions}

The Gram positive, oral coccoid strains, SJM-04, SJM-38, and SJM-65 were isolated from the Outpatient Department (OPD) of the Periodontics and Community Dentistry Clinic, Dr. Ziauddin Ahmad Dental College and Hospital, Aligarh Muslim University, India, by swab sampling as described by Papaioannou et al. [20]. In detail, sterile pure viscose swabs (PW043, Hi-media, Mumbai, India) were used to collect saliva samples from the floor, subgingival, and gingivae of the buccal cavities of patients. Swabs were then immediately immersed into $10 \mathrm{~mL}$ of sterile normal saline solution (NSS) for $30 \mathrm{~min}$. Subsequently, $1000 \mu \mathrm{L}$ samples were spread onto brain heart infusion (BHI) (Cat No. M210, Hi-media, Mumbai, India) agar plates and incubated for $24 \mathrm{~h}$ at $37^{\circ} \mathrm{C}$. Distinct colonies 
were isolated based on phenotypic characteristics (shape, size, color, margin, and colony elevation), purified, cultured, and preserved/stored in $20 \%$ glycerol at $-80^{\circ} \mathrm{C}$.

\subsection{Biochemical Characterization and Antibiotic Sensitivity Profiling of Oral Isolates}

To determine the biochemical properties, IMViC, citrate, catalase, and sugar fermentation assays were performed as described in Bergey's Manual of Systematic Bacteriology [21]. Resistance to 1st, 2nd, 3rd, and 4th generation antibiotic discs, that is, nalidixic acid (NA, $30 \mu \mathrm{g})$ and tetracycline (TE, $30 \mu \mathrm{g})$; norfloxacin (NX, $10 \mu \mathrm{g})$ and cefuroxime (CXM, $30 \mu \mathrm{g})$; cefotaxime (CTX, $30 \mu \mathrm{g})$, levofloxacin (LE, $5 \mu \mathrm{g}$ ) and ceftazidime (CAZ, $30 \mu \mathrm{g})$; and methicillin (MET, $5 \mu \mathrm{g}$ ) (Hi-media, Mumbai, India) was investigated and interpreted as per the CLSI guidelines (2016).

\subsection{Assessment of Biofilm Formation at Different $p H$ Values, Temperatures, and Salinities}

Biofilm formation by the three isolates was assessed at different temperatures, $\mathrm{pH}$ values, and salinities. Georgenia sp. (SJM-04), S. saprophyticus (SJM-38), or R. mucilaginosa (SJM-65) were exposed to these various conditions in 96-wells microtiter plates. To assess the effect of $\mathrm{pH}$ stress, BHI broth was adjusted to $\mathrm{pH} 6.4,7.4$, or 8.4 with $0.1 \mathrm{M} \mathrm{HCl}$ or $0.1 \mathrm{M} \mathrm{NaOH}$. For salinity tolerance, the concentration of sodium chloride $(\mathrm{NaCl})$ was increased from 200 to $1000 \mu \mathrm{g} / \mathrm{mL}$, and to assess the effects of temperature, microtiter plates containing pristine $\mathrm{BHI}$ medium were subjected to $28^{\circ} \mathrm{C}, 37^{\circ} \mathrm{C}$, or $42{ }^{\circ} \mathrm{C}$. Wells were inoculated with $20 \mu \mathrm{L}$ of freshly grown test strains $\left(\cong 1 \times 10^{6} / \mathrm{mL}\right)$ in BHI broth. All experiments were performed in triplicate using independent bacterial colonies and data were averaged.

\subsection{Phylogenetic Characterization of Oral Bacteria}

The $16 \mathrm{~S}$ rRNA gene amplicons of the three Gram positive oral isolates were amplified by PCR using the primers: 16S-27F ( $5^{\prime}$ to $3^{\prime}$ AGAGTTTGATCMTGGCTCAG, $\mathrm{M}=\mathrm{A}$ or C) and 16S-1492R (5' to $3^{\prime}$ ACGGCTACCTTGTTACGA) (Sigma-Aldrich, St. Louis, MO, USA). Qiagen DNeasy kits (Valencia, CA, USA) were used for genomic DNA extraction. For polymerase chain reaction (PCR) amplification, reaction mixtures containing $2.5 \mathrm{U}$ Taq polymerase (Sigma Aldrich), $100 \mu \mathrm{M}$ of each dNTP, $0.2 \mu \mathrm{M}$ of each primer, and $3 \mu \mathrm{L}$ of DNA template (substrate for Taq DNA polymerase) in $50 \mu \mathrm{L}$ of $2 \mathrm{mM} \mathrm{MgCl}_{2}$ solution were processed using a thermal cycler and the following program: $96{ }^{\circ} \mathrm{C}$ for $2 \mathrm{~min}$ (denaturation), followed by 30 amplification cycles of $95^{\circ} \mathrm{C}$ for $15 \mathrm{~s}, 49^{\circ} \mathrm{C}$ for $30 \mathrm{~s}$, and $72{ }^{\circ} \mathrm{C}$ for $1 \mathrm{~min}$, and a final extension at $72{ }^{\circ} \mathrm{C}$ for $1 \mathrm{~min}$. PCR products were purified using the QIAquick-spin PCR Purification Kit (Qiagen, Chatsworth, CA, USA) and sequenced in a DNA sequencing facility using the BioEdit sequence alignment editor. Gene sequence homology was determined using archived 16S rRNA sequences in the GenBank server (www.ncbi.nlm.nih.gov/nucleotide) accessed on 24 January 2019, BLAST Multiple alignments of sequences, and Clustal $\mathrm{W}$ program. Phylogenetic trees were constructed using MEGA 6.0 and the neighbor-joining (NJ) DNA distance algorithm with bootstrap analysis (1000 replications).

\subsection{Physicochemical Characterization of $\mathrm{TiO}_{2} \mathrm{NPS}$}

The physicochemical characteristics of $\mathrm{TiO}_{2} \mathrm{NPs}$ (Sigma-Aldrich, St. Louis, USA; product code 637254) were determined using: (i) a double beam UV-Visible spectrophotometer (UV $5704 S$ from Electronics, India, Ltd., Panchkula, India), (ii) an X-ray diffractometer, (XRD, Rigaku Corporation, Tokyo, Japan), (iii) a transmission electron microscope, (iv) a scanning electron microscope (JSM 6510LV, SEM, Tokyo, Japan), and (v) by energydispersive X-ray (EDX) analyses (Oxford Instruments INCAx-sight EDX spectrometer, Concord, MA, USA). Details of the material characterization methods are provided in our earlier study [22]. Average $\mathrm{TiO}_{2} \mathrm{NP}$ crystalline size was determined using the DebyeScherrer's formula ( $D=0.9 \lambda / \beta \cos \theta$; where $D$ is crystal size, $\lambda$ is $X$-ray wavelength, and $\beta$ is the full-width at half-maximum (FWHM) of the diffraction peak). 


\section{7. $\mathrm{TiO}_{2} \mathrm{NP}$-Induced Cell Growth and Biofilm Inhibition}

\subsubsection{Dose-Dependent Anti-Planktonic Cell Activity of $\mathrm{TiO}_{2} \mathrm{NPs}$}

The dose-dependent antibacterial effects of $\mathrm{TiO}_{2} \mathrm{NPs}$ on isolated strains were determined. First, $100 \mu \mathrm{L}$ of freshly grown $\left(\mathrm{OD}_{600}=0.01\right) \mathrm{SJM}-04$, SJM-38, or SJM-65 strains were added to microtiter wells containing $200 \mu \mathrm{L}$ of $\mathrm{BHI}_{-\mathrm{TiO}_{2} \mathrm{NPs}}(250,500,1000$, or $2000 \mu \mathrm{g} / \mathrm{mL})$ suspensions, and incubated at $37^{\circ} \mathrm{C}$ in triplicate for $24 \mathrm{~h}$. Untreated and treated bacterial cells were then diluted by a factor of $10^{-4}\left(\mathrm{OD}_{600}=0.01\right)$ with sterile distilled water. To determine viable cell counts, $100 \mu \mathrm{L}$ of diluted samples $\left(\mathrm{OD}_{600}=0.01\right)$ were spread on $\mathrm{BHI}$ agar plates and incubated at $37^{\circ} \mathrm{C}$ for $24 \mathrm{~h}$. The viabilities of test strains were determined by comparing the total plate counts (TPCs) of treated and untreated cells. Cells treated with or without $\mathrm{TiO}_{2} \mathrm{NPs}(250 \mu \mathrm{g} / \mathrm{mL})$ were also examined for $\mathrm{TiO}_{2} \mathrm{NP}$-induced morphological damage by SEM. Briefly, untreated and treated bacterial cells were spun at $3000 \mathrm{rpm}$ for $5 \mathrm{~min}$, fixed in glutaraldehyde $(2.5 \%)$ at $4{ }^{\circ} \mathrm{C}$ for $4 \mathrm{~h}$, and cell pellets were dehydrated in an ethanol series (30, 50, 70, and 90\% ethanol for $15 \mathrm{~min} / \mathrm{step})$. A sample (100 $\mu \mathrm{L})$ from each strain was mounted on a clean glass coverslip and coated with a thin layer of gold. Finally, the samples were examined under an SEM at $15 \mathrm{kV}$ and $3000 \times$ [23].

\subsubsection{Dose-Dependent Effect of $\mathrm{TiO}_{2} \mathrm{NPs}$ on Biofilm Formation}

The dose-dependent effects of $\mathrm{TiO}_{2} \mathrm{NPs}$ on biofilm formation by the three isolates were quantified by measuring crystal violet (CV) absorbance, as described by Ahmed et al. [24]. In detail, $100 \mu \mathrm{L}\left(\cong 1 \times 10^{7}\right.$ cells $)$ of freshly grown SJM-04, SJM-38, or SJM-65 cells were added to wells containing 250,500,1000, or $2000 \mu \mathrm{g} / \mathrm{mL}$ of $\mathrm{TiO}_{2} \mathrm{NPs}$ in $200 \mu \mathrm{L}$ of $\mathrm{BHI}$ broth per well. Cultures grown without $\mathrm{TiO}_{2} \mathrm{NPs}$ and sterile $\mathrm{BHI}$ broth alone were used as positive and negative controls, respectively. Micro-well plates were incubated at $37^{\circ} \mathrm{C}$ for $24 \mathrm{~h}$, and then $\mathrm{TiO}_{2} \mathrm{NPs}-\mathrm{BHI}$ suspensions and loosely attached bacteria were carefully removed from the wells. Adherent biofilms on micro-well surfaces were then incubated with $200 \mu \mathrm{L}$ of CV (1\%) for $30 \mathrm{~min}$, were washed with sterile PBS to remove nonabsorbed CV, and air-dried. Biofilm bound CV was then solubilized with ethanol (95\%) and absorbances $\left(\mathrm{OD}_{620}\right)$ were measured using a microplate reader (Thermo Scientific Multiskan EX, REF 51118170, Shanghai, China). In a similar manner, biofilms were formed in 96-well plate for $24 \mathrm{~h}$ and these mature biofilms were treated with $\mathrm{TiO}_{2} \mathrm{NPs}$ to check the dispersal of mature biofilms by $\mathrm{CV}$ assay. In addition, $\mathrm{TiO}_{2} \mathrm{NP}$-induced reductions in biofilm formation were also assessed by microscopy as described by Ahmed et al. [25]. Briefly, using the same conditions mentioned above, biofilms adherent to glass coverslips were washed with PBS to remove loosely attached planktonic cells and then stained with $\mathrm{CV}(1 \%)$ for $30 \mathrm{~min}$. Air-dried biofilms on cover glasses were examined under an optical microscope (Olympus BX60, Model BX60F5, Olympus Optical Co. Ltd. Tokyo, Japan) equipped with a digital camera (Sony, Model no. SSC-DC-58AP, Tokyo, Japan).

\subsection{Statistical Analyses}

Multiple comparisons versus controls were performed by one-way analysis of variance (ANOVA) using the Holm-Sidak method (Sigma Plot ver. 11.0, San Jose, CA, USA). Results are presented as the means \pm SDs of at least two independent experiments performed in triplicate. Statistical significance was accepted for $p$ values $<0.05$.

\section{Results and Discussion}

\subsection{Isolation and Characterization of Oral Bacteria}

The diverse oral microbiota within biofilms obtain the proteins and glycoproteins (mucins) they require to thrive from saliva [26], which is produced at a rate of $1.5-2.0 \mathrm{~mL} / \mathrm{min}$ [27] and normally supports bacterial proliferation of $\cong 10^{9}$ cells $/ \mathrm{mL}$ [28]. Therefore, we collected human saliva with sterile swabs and subsequently added sterile saline solution enriched to near-physiological saline conditions, i.e., to millimolar concentrations of $\mathrm{NaCl}$ and $\mathrm{Ca}^{2+}$ ions. Figure 1 shows the primary characteristics of the colonies of oral isolates, such as color, elevation, margin (Figure 1(AI-AIII,BI-BIII)), morphologies, and 
antibiotic susceptibilities (Figure 1(CI-CIII)). The Gram reactions of Georgenia sp. (SJM-04), S. saprophyticus (SJM-38), and R. mucilaginosa (SJM-65) confirmed their primary identities as Gram positive rods (Figure 1(BI-BIII)) and cocci. Gram positive rod Georgenia sp. withstood nalidixic acid (NA), methicillin (MET), and ceftazidime (CAZ). Gram positive cocci S. saprophyticus was resistant to MET and CAZ, whereas R. mucilaginosa was resistant to tetracycline (TE), cefuroxime (CXM), MET, and CAZ (Table 1). Resistance against thirdgeneration cephalosporin reflects the presence of single-nucleotide polymorphisms (SNPs) that directly increase CAZ hydrolysis by highly conserved class A $\beta$-lactamase [29] bacterial isolates. Similarly, Higashida et al. [30] in a study on eight $S$. saprophyticus strains also showed $\beta$-lactam resistance was due to $m e c A$ gene-mediated resistance. Moreover, transposon mutagenesis experiments have confirmed the role of mecA in conferring methicillin resistance [31]. Besides presenting as urinary tract infection bacterium, S. saprophyticus has been isolated from a variety of other samples such as different brands of minas cheese and beach water [32].

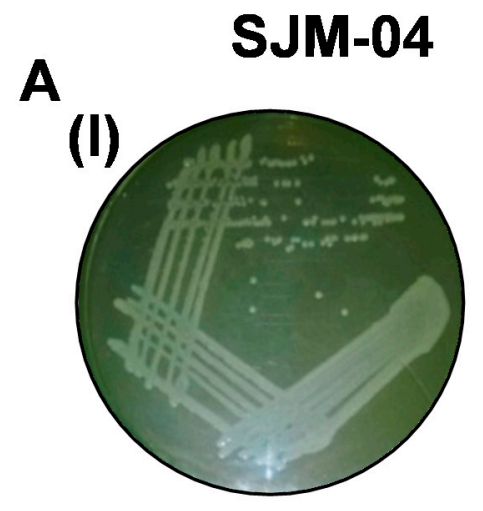

SJM-38

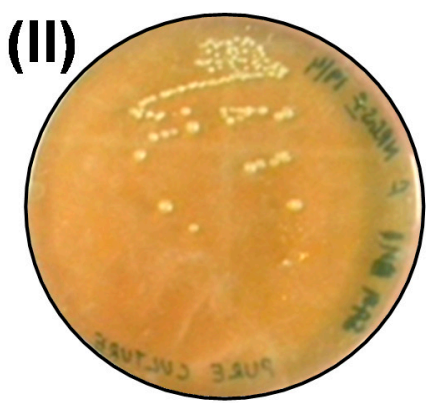

SJM-65
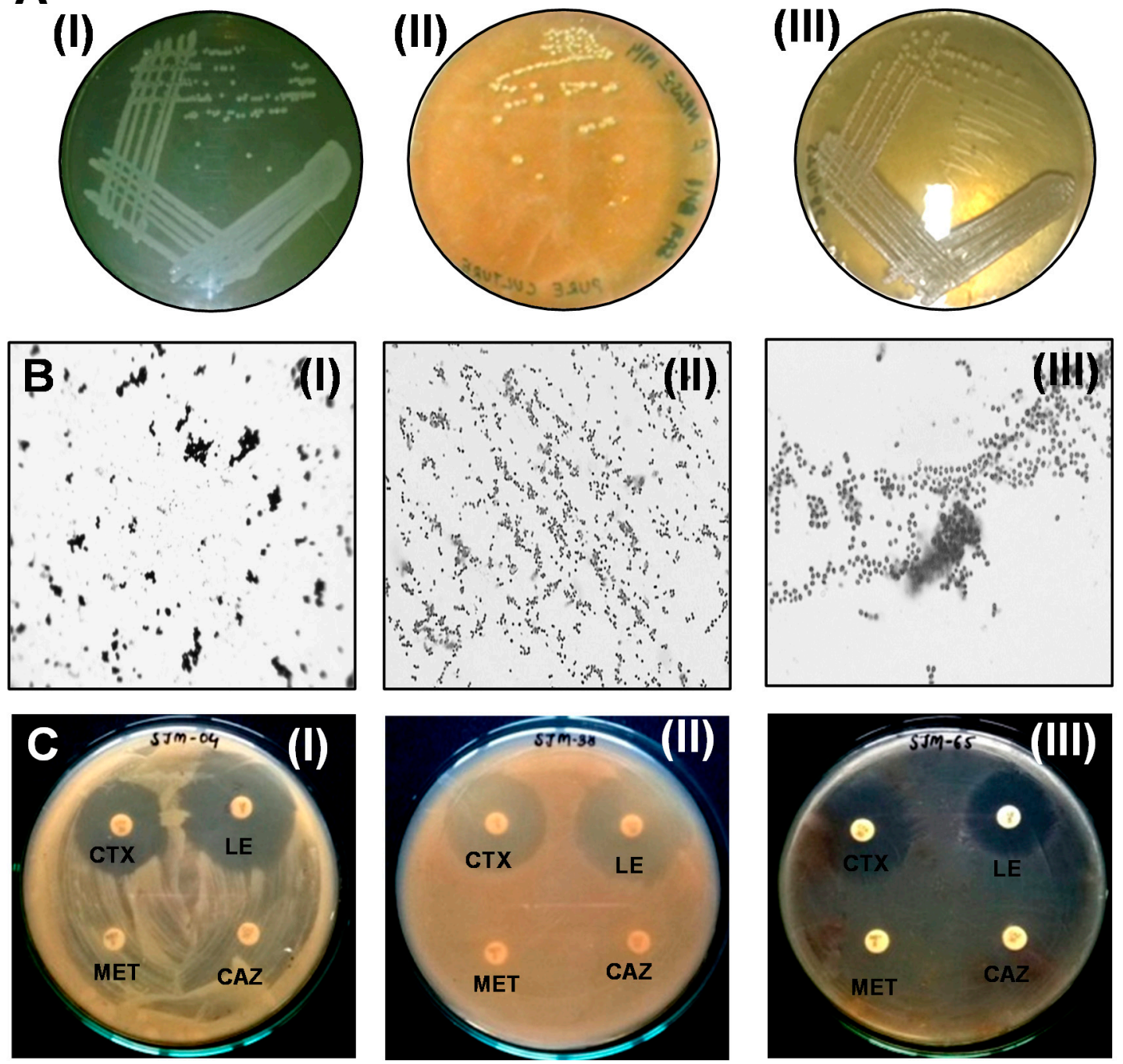

Figure 1. (A,B) show morphological characteristics of (I) SJM-04 (Georgenia sp.), (II) SJM-38 (S. saprophyticus), and (III) SJM65 (R. mucilaginosa) grown onto their respective culture media. (C) shows representative images of the antibiotic sensitivity or resistance of (I) SJM-04 (Georgenia sp.), (II) SJM-65 (S. saprophyticus) and (III) SJM-38 (R. mucilaginosa) against multiple drugs. 
Table 1. Antibiotic sensitivity profiling of Gram positive coccoid oral bacterial isolates.

\begin{tabular}{ccccc}
\hline \multirow{2}{*}{ Antibiotics } & $\begin{array}{c}\text { Concentration } \\
(\mu \mathrm{g} / \text { disc })\end{array}$ & \multicolumn{2}{c}{ Zone of Inhibition (mm) \pm S.D. } \\
\cline { 3 - 5 } & 30 & $0 \pm 0(\mathrm{R})$ & $23 \pm 2(\mathrm{~S})$ & $15 \pm 3(\mathrm{~S})$ \\
\cline { 3 - 5 } Nalidixic acid (NA) & 10 & $25 \pm 5(\mathrm{~S})$ & $27 \pm 3(\mathrm{~S})$ & $0 \pm 0(\mathrm{R})$ \\
Tetracycline (TE) & 10 & $30 \pm 3(\mathrm{~S})$ & $27 \pm 4(\mathrm{~S})$ & $26 \pm 4(\mathrm{~S})$ \\
Norfloxacin (NX) & 30 & $18 \pm 2(\mathrm{~S})$ & $32 \pm 3(\mathrm{~S})$ & $0 \pm 0(\mathrm{R})$ \\
Cefuroxime (CXM) & 30 & $26 \pm 4(\mathrm{~S})$ & $30 \pm 4(\mathrm{~S})$ & $31 \pm 2(\mathrm{~S})$ \\
Cefotaxime (CTX) & 5 & $32 \pm 3(\mathrm{~S})$ & $28 \pm 5(\mathrm{~S})$ & $29 \pm 3(\mathrm{~S})$ \\
Levofloxacin (LE) & 5 & $0 \pm 0(\mathrm{R})$ & $0 \pm 0(\mathrm{R})$ & $0 \pm 0(\mathrm{R})$ \\
Methicillin (MET) & 30 & $0 \pm 0(\mathrm{R})$ & $0 \pm 0(\mathrm{R})$ & $0 \pm 0(\mathrm{R})$ \\
Ceftazidime (CAZ) & & &
\end{tabular}

\subsection{Biochemical Characterizations of the Three Oral Isolates}

The survival of oral communities largely relies on the nature of the salivary environment ( $\mathrm{pH}$, temperature, and ionic strength) and the intrinsic metabolic responses of these communities to the salivary biochemical milieu. We subjected the oral isolates to 14 different biochemical tests. The biochemical abilities of SJM-04, SJM-38, and SJM-65, to metabolize monosaccharide and disaccharide and produce citrate, cytochrome oxidase, nitrate reductase, amylase, and lipase were determined using Voges-Proskauer (VP), sucrose fermentation, citrate, catalase, nitrate reductase, starch, and lipid hydrolysis assays, respectively (Table 2). According to Kampfer et al. [33], most strains of Georgenia species are able to utilize glucose and sucrose, and also showed that a Gram positive coccoid Georgenia sp. ( 1-1.5 mm) isolate with a positive oxidase reaction demonstrated aerobic metabolism. The isolate SJM-38, identified as S. saprophyticus, a Gram positive cocci, is commonly found in the female urinary tract [34], but has also been isolated from meat, raw milk, cheese products [35], and the marine environment in polluted and recreational waters [32,36]. Recently, Uttatree and Charoenpanicha [37] reported certain biochemical properties of $S$. saprophyticus including fermentation and oxidation of glucose and sucrose, as we detected in the current study. Additionally, S. saprophyticus strains exhibited the production of citrate, catalase, amylase, and lipase (Table 2). The negative reaction of VP was well supported by the literature [38]. At least four types of nitrate-reducing enzymes have been reported in oral microflora, (i) periplasmic (NAP), (ii) membrane-bound (NAR), (iii) ferredoxin-dependent assimilatory (FdNAS), and (iv) flavin-dependent assimilatory (FAD-NAS), which exhibit distinct biochemical and catalytic properties of bacterial species including $R$. mucilaginosa, $R$. dentocariosa, and S. epidermidis [39]. Moreover, the isolate SJM-65 R. mucilaginosa was found to share a positive catalase reaction and a coccoid morphology with Staphylococci species [40]. Recently, Dhital et al. [41] reported a common starch hydrolytic reaction, whereby oral isolates secrete amylolytic enzymes that convert complex starch oligomers into simpler forms.

\subsection{Phylogenetic Identification}

Phylogenetic characterizations of the three bacterial isolates viz., SJM-04, SJM-38, and SJM-65 were carried out by analyzing 16S rRNA gene sequence homologies. PCR amplification (Figure 2A) and sequencing yielded partial nucleotide sequences of the $16 \mathrm{~S}$ rRNA genes of SJM-04, SJM-38, and SJM-65, which were deposited in NCBI GenBank under accession nos. KT922165, KT922167, and KT922172, respectively. Phylogenetic analysis results of SJM-04, SJM-38, and SJM-65 concurred with the results of their presumptive identification as Gram positive cocci, and identified them as Georgenia sp. (accession no. KT922165), S. saprophyticus (accession no. KT922167), and R. mucilaginosa (accession no. KT922172), respectively. Furthermore, BLAST multiple alignments of the 16S rRNA sequence of isolate SJM-04 showed gene sequence homology with Georgenia sp. (accession no. KT922165) and close relatedness with the earlier recognized Georgenia species Georgenia soli strain CC-NMPT-T3 (FN356976) [33] and G. daeguensis strain 2C6-43 (HQ246163) [42], as 
shown in Figure 2B. Phylogenetic comparison of the Staphylococcus isolate (SJM-38) showed greatest similarity with S. saprophyticus strain ATCC 15305 (Figure 2B). In an identical manner, isolate SJM-65 was identified as R. mucilaginosa (accession no. KT922172) and showed close relatedness to all recognized species of genus Rhothia: $R$. mucilaginosa DSM 20746 and R. dentocariosa ATCC-17931 (Figure 2B).

Table 2. Biochemical characterization of Gram positive coccoid oral bacterial isolates.

\begin{tabular}{cccc}
\hline Biochemical Assay & \multicolumn{3}{c}{ Bacterial Isolates } \\
\cline { 2 - 4 } Indole test & SJM-04 & SJM-38 & SJM-65 \\
Methyl red & - & - & - \\
Voges-Proskauer & - & - & - \\
Citrate & + & + & + \\
Sucrose fermentation & + & + & - \\
Lactose fermentation & + & - & + \\
Dextrose fermentation & - & + & + \\
Catalase & - & + & + \\
Oxidase & + & + & + \\
Nitrate reduction & - & + & + \\
Starch Hydrolysis & + & + & - \\
Lipid Hydrolysis & + & - & + \\
Urease & - & & + \\
\hline
\end{tabular}

_' and '+' signs denote a negative and positive reaction, respectively.
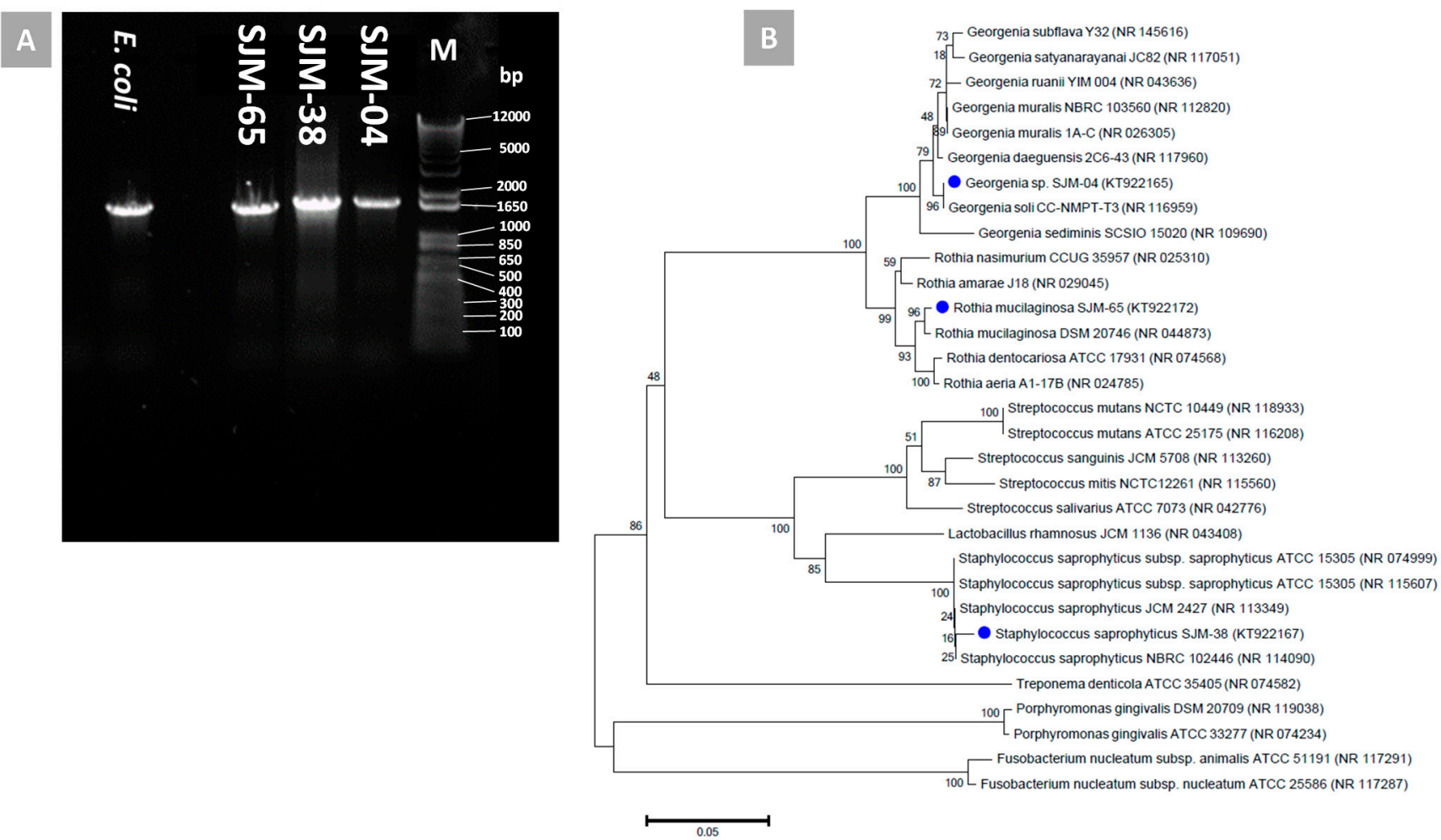

Figure 2. (A) shows an agarose gel electrophoresis result for purified $16 \mathrm{~S}$ rDNA amplicons obtained after PCR amplification using genomic DNAs extracted from biofilm forming oral isolates as templates. (B) shows an unrooted neighbor-joined phylogenetic tree of closely related phylogenetic species based on 16S rRNA gene sequences of isolates SJM-04, SJM-38, and SJM-38 (marked with blue symbols). Sequences were aligned using the Clustal W sequence alignment tool in MEGA 7.0 software. The GenBank accession numbers of isolates and closely related species are presented in parenthesis. Bootstrap percentage values as obtained from 1000 replications of the data set are given at tree nodes. The scale bar represents the mean number of nucleotide substitutions per site. 


\subsection{Effects of Temperature, $\mathrm{pH}$, and $\mathrm{NaCl}$ on Biofilm Formation}

Growth patterns of bacterial cells proportionally affect the growths of biofilms, which are largely composed of non-replicating persister cells in an extracellular polysaccharide (EPS) matrix [43,44]. Unlike free planktonic cells, biofilm embedded/phenotypically altered cells become acclimatized to withstand microenvironmental stresses such as temperature, $\mathrm{pH}$, and ionic strength changes. Hence, the present study primarily ascertains the optimal biofilm formation by modulating the physiochemical growth conditions for Georgenia sp. (SJM-04), S. saprophyticus (SJM-38), and R. mucilaginosa (SJM-65). Our results demonstrated (Figure $3 \mathrm{~A})$ that a lower temperature $\left(28^{\circ} \mathrm{C}\right)$ had a negligible effect on biofilm formation by bacterial strains as compared with the control temperature $\left(37^{\circ} \mathrm{C}\right)$. However, temperature elevation to $42{ }^{\circ} \mathrm{C}$ significantly limited biofilm adherence to $7.2 \pm 1.0 \%(p<0.05)$ for strain Georgenia sp. (SJM-04), and S. saprophyticus (SJM-38) and R. mucilaginosa (SJM-65) could not survive this temperature. It is widely accepted that the optimum temperature is directly related to the metabolic activities of microbial enzymes, and thus, nutrient metabolism [45] and biofilm formation [46].
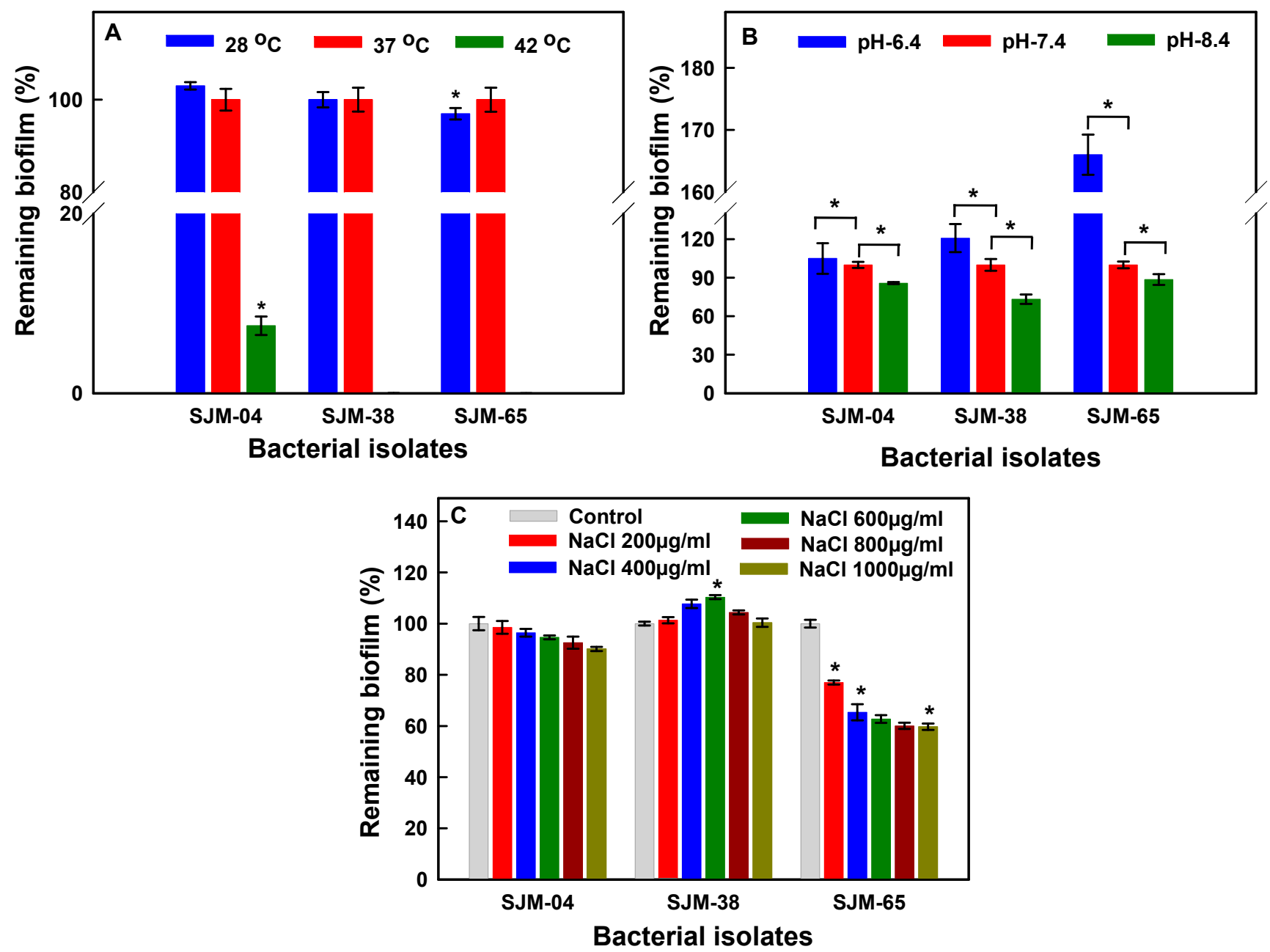

Figure 3. Assessment of biofilm formation as a function of temperature (A), $\mathrm{pH}(\mathbf{B})$, and $\mathrm{NaCl}$ concentration $(\mathbf{C})$. $^{\text {(*' }}$ denotes the statistical difference at $p \leq 0.05$ between control and treated groups.

In the present study, an increase or decrease in one $\mathrm{pH}$ unit from the control level $\mathrm{pH}-$ 7.4) significantly $(p<0.05)$ affected the interaction between isolates Georgenia sp. (SJM-04), S. saprophyticus (SJM-38), and R. mucilaginosa (SJM-65) and glass surfaces (Figure 3B). At $\mathrm{pH}$ 6.4, significant $(p<0.05)$ increases in biofilm formation were observed for Georgenia sp. (SJM-04), S. saprophyticus (SJM-38), and R. mucilaginosa (SJM-65) strains by $105.2 \%$, 
$120.7 \%$, and $166 \%$, respectively, as compared to $100 \%$ for controls at $\mathrm{pH} 7.4)$. Conversely, an increase in $\mathrm{pH}$ to 8.4 caused significant $(p<0.05)$ reductions in biofilm to $85.77 \pm 0.80$, $73.26 \pm 3.6$, and $88.57 \pm 4.2 \%$, respectively (Figure $3 \mathrm{~B}$ ). Thus, our results indicate that a slight change in external $\mathrm{pH}$ can overwhelm the cellular processes that support oral bacterial biofilms, which may include the synthesis of proteins [47] and polysaccharides [48] and the membrane electrochemical gradient [49]. Earlier studies on acyl-homoserine lactone (AHL) production in quorum sensing (QS) systems of marine bacteria demonstrated salinity dependence [50], and suggested that salinity is a significant factor for QS [51]. Therefore, we also investigated biofilm growth in the presence of different concentrations $(200,400$, 600,800 , and $1000 \mu \mathrm{g} / \mathrm{mL}$ ) of $\mathrm{NaCl}$. Results demonstrated a dose-dependent decrease in biofilm formation from $98.5 \pm 2.5 \%$ to $90.0 \pm 8.7 \%$ and from $76.9 \pm 2.8 \%$ to $59.7 \pm 1.2 \%$ on increasing the $\mathrm{NaCl}$ concentration from 200-1000 $\mu \mathrm{g} / \mathrm{mL}$ for Georgenia sp. (SJM-04) and R. mucilaginosa (SJM-65), respectively (Figure 3C). Interestingly, under identical conditions, biofilm formation by $S$. saprophyticus (SJM-38) slightly increased on increasing the $\mathrm{NaCl}$ $(200-1000 \mu \mathrm{g} / \mathrm{mL})$ concentration $101.3 \pm 1.2 \%, 107.7 \pm 1.6 \%, 110.3 \pm 0.7 \%, 104.4 \pm 0.7 \%$ and $100.4 \pm 1.6 \%$, respectively (Figure 3C). According to Moretro et al. [52], $\mathrm{NaCl}$ and glucose stimulate adherence and increase the stability of biofilms formed by Staphylococci genus due to the presence of the icaA gene, which is positively correlated with strong biofilm formation. Recently, Xu et al. [53] also reported that $\mathrm{NaCl}$ significantly increased biofilm formation by $S$. aureus in an concentration-dependent manner

\subsection{Physicochemical Characteristics of $\mathrm{TiO}_{2} \mathrm{NPS}$}

Surface plasmon resonance (SPR) happens due to the collective oscillations of electrons at the resonant frequency of metal NPs and results in absorption in the UV-Visible region [13]. In the present study, the appearance of a sharp peak at an absorption wavelength $\left(\lambda_{\max }\right)$ of $347 \mathrm{~nm}$ in the UV-Vis absorption spectrum is likely to be due to localized SPR of $\mathrm{TiO}_{2} \mathrm{NPs}$ in aqueous suspension (Figure 4A). Furthermore, SPR frequencies of NPs are considered to be directly correlated with nanoparticle size, shape, and crystalline nature [54]. Therefore, we analyzed the morphology and composition and determined the size and crystallinity of $\mathrm{TiO}_{2} \mathrm{NPs}$. SEM analysis showed NPs had pleomorphic shapes, though the majority were spherical (Figure $4 \mathrm{~B}$ ). The EDX spectrum of $\mathrm{TiO}_{2} \mathrm{NPs}$ revealed the presence of titanium (Ti) and oxygen (O) at elemental compositions of $32.74 \%$ and $67.26 \%$, respectively (Figure $4 \mathrm{C}$ ). TEM results showed $\mathrm{TiO}_{2} \mathrm{NPs}$ shapes included spherical, oval, and hexagonal particles (Figure 4D) with sizes ranging from 5-25 nm (average diameter $14.7 \mathrm{~nm}$ ) (Figure 4E). Furthermore, the XRD pattern of $\mathrm{TiO}_{2} \mathrm{NPs}$ (Figure 4F), obtained by using cell parameters: a-3.8101 $\AA, b-3.8101 \AA$, and c-9.3632 $\AA ; \alpha=\beta=\gamma=90^{\circ}$ and centered tetragonal phase, showed the anatase phase $\mathrm{TiO}_{2}-\mathrm{NPs}$ (JCPDS 21-1272) and peaks at $2 \theta$ values of $24.6^{\circ}, 37.2^{\circ}, 47.5^{\circ}, 53.4^{\circ}, 54.6^{\circ}$, and $62.2^{\circ}$ corresponding to (101), (004), (200), (1050), (211), and (204) HKL miller indices, respectively. Average size by XRD was determined to be $13.7 \mathrm{~nm}$ based on full-width at half-maximum (FWHM) of the 101 reflection peak, which matched well with that of the TEM size. 
A

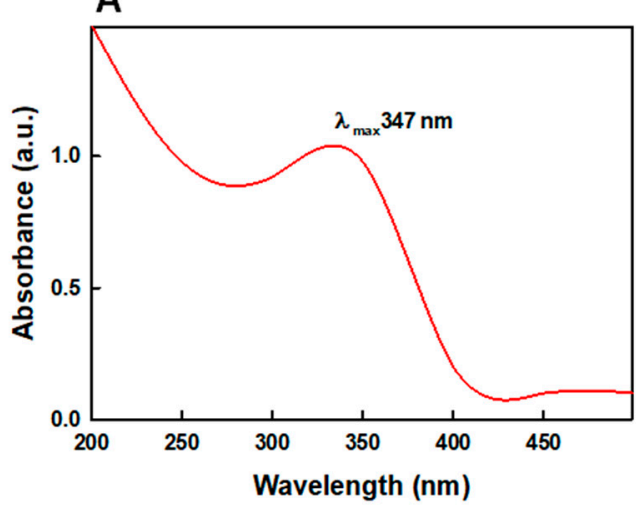

D

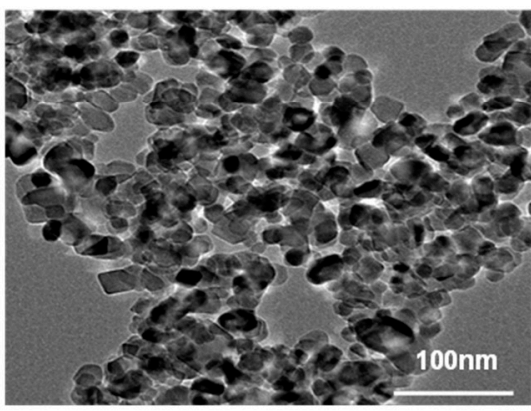

B

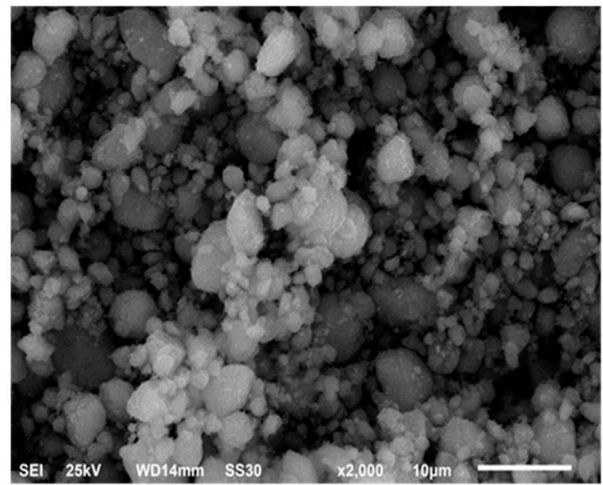

E

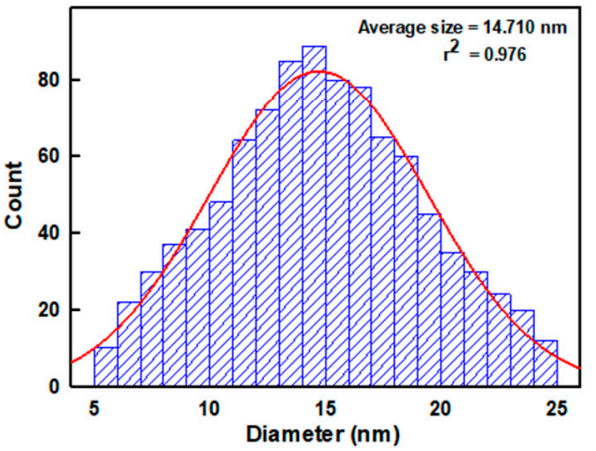

C

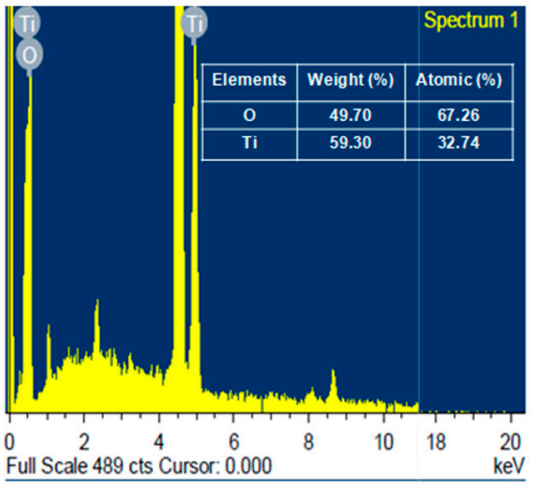

$\mathbf{F}$

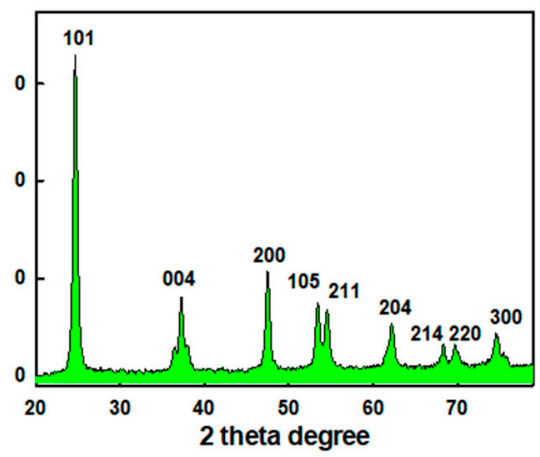

Figure 4. UV-Vis absorption spectrum of $\mathrm{TiO}_{2} \mathrm{NPs}$ showing the characteristic SPR peak at $347 \mathrm{~nm}(\mathrm{~A})$. (B,C) show the SEM image and energy dispersive $\mathrm{X}$-ray analysis of $\mathrm{TiO}_{2} \mathrm{NPs}$, respectively. (D) shows a representative TEM micrograph of $\mathrm{TiO}_{2} \mathrm{NPs}$ and (E) shows the $\mathrm{TiO}_{2} \mathrm{NP}$ size distribution. (F) shows the X-ray diffraction pattern of $\mathrm{TiO}_{2} \mathrm{NPs}$.

The dose-dependent antibacterial effect of $\mathrm{TiO}_{2} \mathrm{NPs}(250-2000 \mu \mathrm{g} / \mathrm{mL})$ on oral bacterial strains: Georgenia sp. (SJM-04), S. saprophyticus (SJM-38), and R. mucilaginosa (SJM-65) exhibited significant growth inhibition over $24 \mathrm{~h}$ (Figure 5). We found that treatment with $\mathrm{TiO}_{2} \mathrm{NPs}$ at $250,500,1000$, and $2000 \mu \mathrm{g} / \mathrm{mL}$ for $24 \mathrm{~h}$ reduced the viability of Georgenia sp. (SJM-04), S. saprophyticus (SJM-38), and R. mucilaginosa (SJM-65) to 58.0 $\pm 5.2,52.0 \pm 3.8$, $38.0 \pm 4.5$ and $4.5 \pm 2.0 \%$ (Figure $5(\mathrm{AI})$ ); $91.0 \pm 3.8,78.0 \pm 5.2,25.0 \pm 4.5$ and $5.0 \pm 2.0 \%$ (Figure 5(BI)); and, $90.0 \pm 5.2,55.0 \pm 4.8,41.0 \pm 4.5$ and $38.0 \pm 3.0 \%$ (Figure $5(\mathrm{CI})$ ), respectively. The mechanisms responsible for the antibacterial activities of various metal-oxide NPs are unclear, though it is believed that the presence of dissolved metal ions on surfaces of NPs and/or NP-induced oxidative stress are involved [14]. Specifically, in the case of anatase $\mathrm{TiO}_{2} \mathrm{NPs}$, the photocatalytic activity of $\mathrm{TiO}_{2}$ in aqueous environments results in the release of hydroxyl radicals $(\mathrm{OH} \bullet)$ and the subsequent formation of superoxide radicals $\left(\mathrm{O}_{2}{ }^{-}\right)$[55]. Therefore, it could be argued that ROS may attack polyunsaturated phospholipids in bacteria and cause DNA damage [23,25]. Additionally, we treated Georgenia sp. (Figure 5(AIII)), S. saprophyticus (Figure 5(BIII)), and R. mucilaginosa (Figure 5(CIII)) with $\mathrm{TiO}_{2} \mathrm{NPs}$ at $250 \mu \mathrm{g} / \mathrm{mL}$ and examined their effects by SEM. We observed that $\mathrm{TiO}_{2} \mathrm{NP}-$ bacteria interactions caused morphological changes such as shrinkage and cell membrane damage, possibly because NPs penetrated bacterial membranes and compromised cell membrane permeability [56]. 

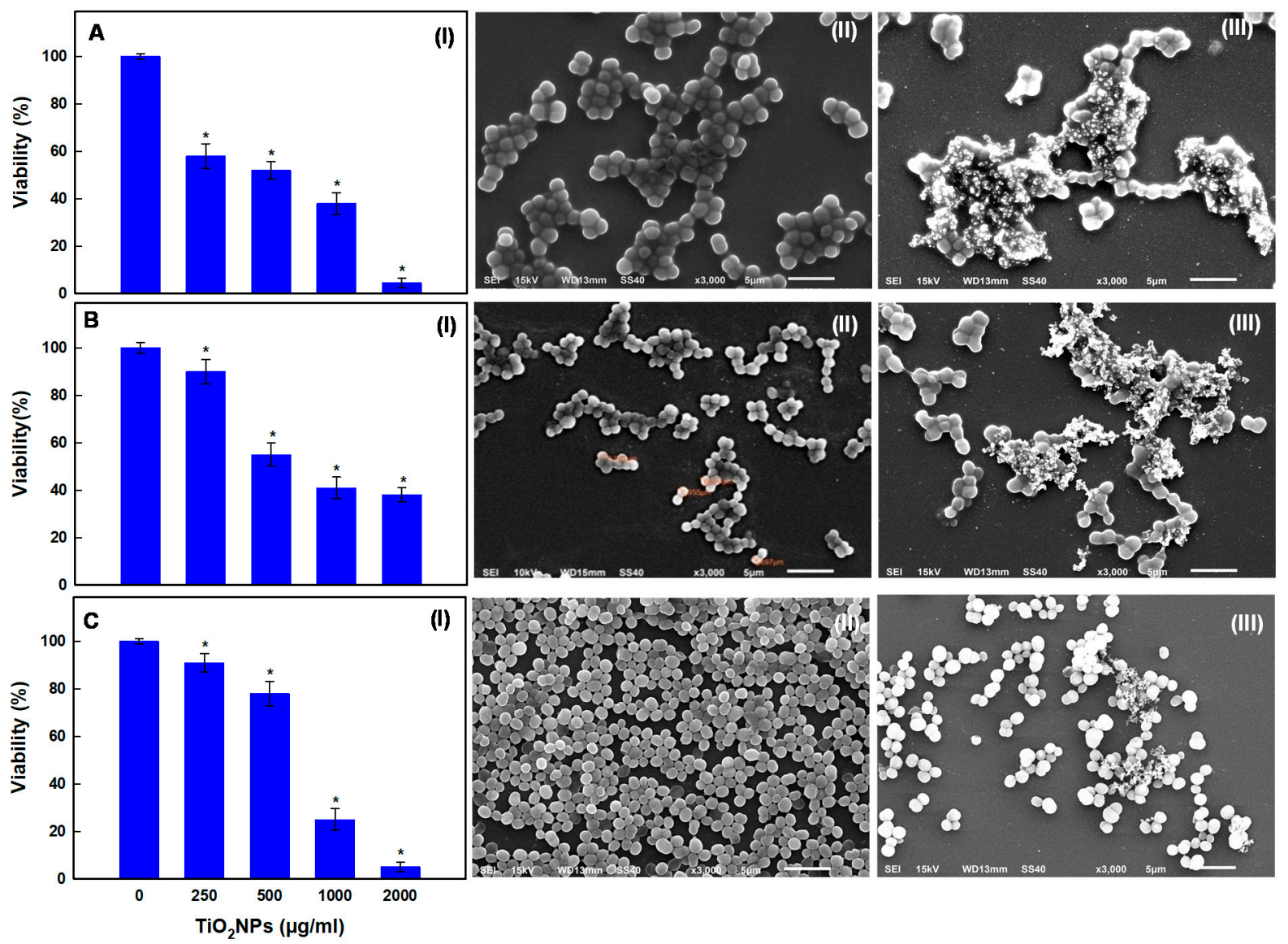

Figure 5. Reductions in the percentage viability of Gram positive SJM-04 (AI), SJM-38 (BI), and SJM-65 (CI) treated with $250,500,1000$, or $2000 \mu \mathrm{g} / \mathrm{mL}$ concentrations of $\mathrm{TiO}_{2} \mathrm{NPs}$ for $24 \mathrm{~h}$. SEM micrographs showing morphological changes in SJM-04 (AIII), SJM-38 (BIII), and SJM-65 (CIII) cells after treatment with $\mathrm{TiO}_{2} \mathrm{NPs}$ at $250 \mu \mathrm{g} / \mathrm{mL}$ vs. untreated control cells (AII-CII). ${ }^{* \prime}$ denotes the statistical difference at $p \leq 0.05$ between control and treated groups.

\subsection{Dose-Dependent Effects of $\mathrm{TiO}_{2} \mathrm{NPS}$ on Biofilm Formation}

The effects of $\mathrm{TiO}_{2} \mathrm{NPs}$ concentration $(250-2000 \mu \mathrm{g} / \mathrm{mL})$ on the adherence of the biofilms produced by the three oral strains were also examined. The biofilms produced by various bacterial species play decisive roles in the way they respond to their immediate surroundings. Treatment of Georgenia sp., S. saprophyticus, and R. mucilaginosa with $\mathrm{TiO}_{2} \mathrm{NPs}$ at $250,500,1000$, or $2000 \mu \mathrm{g} / \mathrm{mL}$ for $24 \mathrm{~h}$ significantly reduced biofilm adhesion on glass surfaces to $55.5 \pm 3.2,46.4 \pm 4.1,35.3 \pm 4.2$, and $13.1 \pm 3.2 \%$; $48.4 \pm 3.2,42.4 \pm 4.1$, $30.3 \pm 1.9$, and $18.1 \pm 2.0 \%$; and $68.3 \pm 3.4,50.2 \pm 3.3,43.3 \pm 3.2$, and $33.3 \pm 3.2 \%$, respectively (Figure $6 \mathrm{~A}$ ). Taken together, these results show that $\mathrm{TiO}_{2} \mathrm{NPs}$ reduced biofilm adherence in a concentration-dependent manner. Recently, Sodagar et al. [57] reported that treatment with $5 \% \mathrm{TiO}_{2} \mathrm{NPs}$ significantly inhibited biofilm formation by the Gram positive oral bacteria S. mutans and S. sanguinis. Additionally, the micrographs presented in Figure $6 \mathrm{~B}-\mathrm{D}$ show than $\mathrm{TiO}_{2} \mathrm{NPs}$ reduced biofilm formation by Georgenia sp. (Figure 6(BIIBV)), S. saprophyticus (Figure 6(CII-CV)), and R. Mucilaginosa (Figure 6(DII-DV)) in a concentration-dependent manner versus untreated controls (Figure 6(BI,DI)). In assessing the reduction in mature $\left(24 \mathrm{~h}\right.$ ) biofilms of the three tested strains of $\mathrm{TiO}_{2} \mathrm{NPs}$ by $\mathrm{CV}$ assay, only 1000 or $2000 \mu \mathrm{g} / \mathrm{mL}$ resulted in significant destruction of mature biofilms, suggesting that $\mathrm{TiO}_{2} \mathrm{NPs}$ are more efficient against developing biofilms at $250-500 \mu \mathrm{g} / \mathrm{mL}$, but they can also destroy biofilms at higher concentrations of 1000 or $2000 \mu \mathrm{g} / \mathrm{mL}$ (Supplementary Materials, Figure S1). 

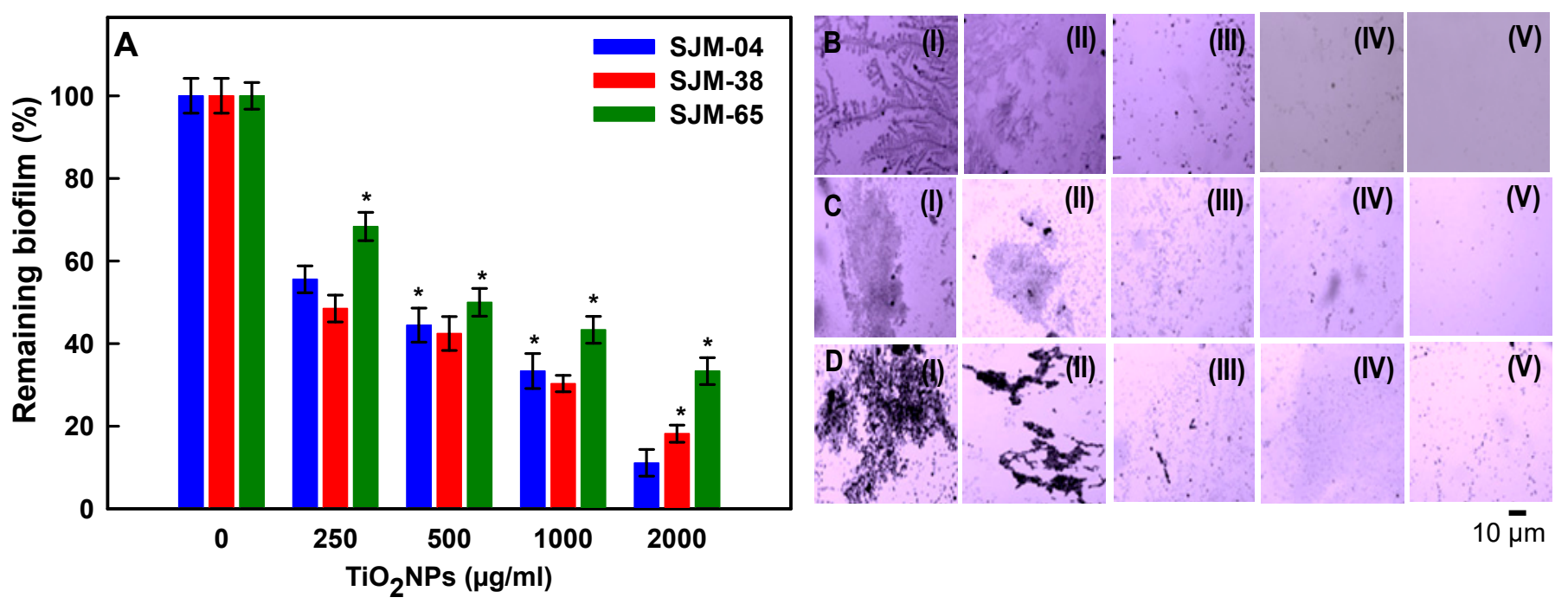

Figure 6. Reductions in biofilm formation after treatment with $\mathrm{TiO}_{2} \mathrm{NPs}$ at 250, 500, 1000, or $2000 \mu \mathrm{g} / \mathrm{mL}$ for $24 \mathrm{~h}$ (Panel A). Error bars denote standard deviations of triplicate samples (A). Microscopic images showing reduced biofilm formation by

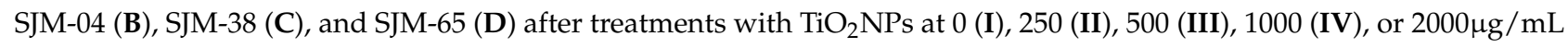
(V). ${ }^{* \prime}$ denotes the statistical difference at $p \leq 0.05$ between control and treated groups.

\section{Conclusions}

The MDR Gram positive cocci Georgenia sp., R. mucilaginosa, and S. saprophyticus isolated from oral cavity were successfully characterized for their morphologies, biochemical characteristics, phylogenetic relatedness, and biofilm formation at various $\mathrm{pH}$, temperatures and salt concentrations. Exposure of these strains to crystalline $\mathrm{TiO}_{2} \mathrm{NPs}$ (5> size $<25 \mathrm{~nm}$ ) significantly inhibited their planktonic cell growth and biofilm formation. Three exposure scenarios including low $(250 \mu \mathrm{g} / \mathrm{mL})$, moderate $(500 \mu \mathrm{g} / \mathrm{mL})$, and high $(1000-2000 \mu \mathrm{g} / \mathrm{mL})$ doses of $\mathrm{TiO}_{2} \mathrm{NPs}$ decreased the biofilm in a dose-dependent manner, suggesting that the concentration of $\mathrm{TiO}_{2} \mathrm{NPs}$, apart from other factors, could be the main reason why they act as both an antibacterial and antibiofilm agent to the tested oral bacteria. Our results suggest that $\mathrm{TiO}_{2} \mathrm{NPs}$ with the following physicochemical profile: absorption $\lambda_{\max }$ of $347 \mathrm{~nm}$, diameter $5-25 \mathrm{~nm}$, average crystalline size $13.7 \mathrm{~nm}$, tetragonal anatase phase, and spherical shape might be a suitable choice for treating oral biofilms, can potentially be applied in orthodontics as a potential oral hygiene alternative to conventional rinses and for the suppression of cariogenic biofilm formation. Further in vivo biofilm studies on the interaction of $\mathrm{TiO}_{2} \mathrm{NPs}$ with human saliva and the effect on NP's shape, size, and metal release are warranted for preparing the most effective antibiofilm formulations.

Supplementary Materials: The following are available online at https:/ / www.mdpi.com/article/10 .3390 / pharmaceutics13101564/s1, Figure S1. Reduction in mature (24 h) biofilms of strain SJM-04, SJM-38, and SJM-65 by TiO2NPs. ${ }^{* \prime}$ represents statistical difference at $p \leq 0.05$.

Author Contributions: Conceptualization, J.M. and A.S.; methodology, S.F., K.A. and B.A.; software, J.M., S.F. and K.A.; validation, J.M., J.L. and A.M.E.; formal analysis, B.A., K.A. and A.A.A.K.; investigation, J.M., S.F., K.A. and B.A.; resources, J.M., A.M.E. and J.L.; data curation, S.F., K.A. and A.A.A.K.; writing-original draft preparation, K.A. and B.A.; writing-review and editing, J.M., K.A., B.A., A.S. and J.L.; supervision, J.M.; project administration, J.M. and B.A.; funding acquisition, J.M., A.M.E. and J.L. All authors have read and agreed to the published version of the manuscript.

Funding: This research was funded by the Priority Research Centers Program through the National Research Foundation of Korea (NRF) funded by the Ministry of Education (2014R1A6A1031189) and the Researchers Supporting Project Number (RSP-2021/31), King Saud University, Riyadh, Saudi Arabia. 
Institutional Review Board Statement: The use of saliva samples for isolation of bacteria was approved by the Internal Ethical Committee, Aligarh Muslim University, Uttar Pradesh, India.

Informed Consent Statement: Informed consent was obtained from all subjects (patients) involved in the study.

Acknowledgments: This work was supported by the Priority Research Centers Program through the National Research Foundation of Korea (NRF) funded by the Ministry of Education (2014R1A6A1031189). The authors extend their appreciation to the Researchers Supporting Project Number (RSP-2021/31), King Saud University, Riyadh, Saudi Arabia.

Conflicts of Interest: The authors declare no conflict of interest.

\section{References}

1. Palmer, R.J., Jr. Composition and development of oral bacterial communities. Periodontology 2000 2014, 64, 20-39. [CrossRef]

2. Muñoz-González, I.; Thurnheer, T.; Bartolome, B.; Moreno-Arribas, M.V. Red wine and oenological extracts display antimicrobial effects in an oral bacteria biofilm model. J. Agric. Food Chem. 2014, 62, 4731-4737. [CrossRef] [PubMed]

3. Flemming, H.-C.; Wingender, J. The biofilm matrix. Nat. Rev. Microbiol. 2010, 8, 623-633. [CrossRef] [PubMed]

4. Tawakoli, P.N.; Al-Ahmad, A.; Hoth-Hannig, W.; Hannig, M.; Hannig, C. Comparison of different live/dead stainings for detection and quantification of adherent microorganisms in the initial oral biofilm. Clin. Oral Investig. 2013, 17, 841-850. [CrossRef] [PubMed]

5. Roberts, A.P.; Mullany, P. Oral biofilms: A reservoir of transferable, bacterial, antimicrobial resistance. Expert Rev. Anti-Infect. Ther. 2010, 8, 1441-1450. [CrossRef]

6. Potera, C. Antibiotic resistance: Biofilm dispersing agent rejuvenates older antibiotics. Environ. Health Perspect. 2010, 118, A288. [CrossRef]

7. Da Silva, B.R.; De Freitas, V.A.A.; Carneiro, V.A.; Arruda, F.V.S.; Lorenzón, E.N.; De Aguiar, A.S.W.; Cilli, E.M.; Cavada, B.S.; Teixeira, E.H. Antimicrobial activity of the synthetic peptide Lys-a1 against oral streptococci. Peptides 2013, 42, 78-83. [CrossRef]

8. Beikler, T.; Flemmig, T.F. Oral biofilm-associated diseases: Trends and implications for quality of life, systemic health and expenditures. Periodontology 2000 2011, 55, 87-103. [CrossRef]

9. Lu, M.; Ge, Y.; Qiu, J.; Shao, D.; Zhang, Y.; Bai, J.; Zheng, X.; Chang, Z.; Wang, Z.; Dong, W. Redox/pH dual-controlled release of chlorhexidine and silver ions from biodegradable mesoporous silica nanoparticles against oral biofilms. Int. J. Nanomed. 2018, 13, 7697. [CrossRef]

10. Liang, G.; Shi, H.; Qi, Y.; Li, J.; Jing, A.; Liu, Q.; Feng, W.; Li, G.; Gao, S. Specific Anti-biofilm Activity of Carbon Quantum Dots by Destroying, P. gingivalis Biofilm Related Genes. Int. J. Nanomed. 2020, 15, 5473. [CrossRef]

11. Coman, A.N.; Mare, A.; Tanase, C.; Bud, E.; Rusu, A. Silver-deposited nanoparticles on the titanium nanotubes surface as a promising antibacterial material into implants. Metals 2021, 11, 92. [CrossRef]

12. Tanase, C.; Berta, L.; Mare, A.; Man, A.; Talmaciu, A.I.; Roșca, I.; Mircia, E.; Volf, I.; Popa, V.I. Biosynthesis of silver nanoparticles using aqueous bark extract of Picea abies L. and their antibacterial activity. Eur. J. Wood Wood Prod. 2020, 78, 281-291. [CrossRef]

13. Zane, A.; Zuo, R.; Villamena, F.A.; Rockenbauer, A.; Foushee, A.M.D.; Flores, K.; Dutta, P.K.; Nagy, A. Biocompatibility and antibacterial activity of nitrogen-doped titanium dioxide nanoparticles for use in dental resin formulations. Int. J. Nanomed. 2016, 11, 6459. [CrossRef] [PubMed]

14. Khan, S.T.; Al-Khedhairy, A.A.; Musarrat, J. $\mathrm{ZnO}$ and $\mathrm{TiO}_{2}$ nanoparticles as novel antimicrobial agents for oral hygiene: A review. J. Nanopart. Res. 2015, 17, 1-16. [CrossRef]

15. Allaker, R.P.; Memarzadeh, K. Nanoparticles and the control of oral infections. Int. J. Antimicrob. Agents 2014, 43, 95-104. [CrossRef]

16. Yazdi, A.S.; Guarda, G.; Riteau, N.; Drexler, S.K.; Tardivel, A.; Couillin, I.; Tschopp, J. Nanoparticles activate the NLR pyrin domain containing 3 (Nlrp3) inflammasome and cause pulmonary inflammation through release of IL-1 $\alpha$ and IL-1 $\beta$. Proc. Natl. Acad. Sci. USA 2010, 107, 19449-19454. [CrossRef] [PubMed]

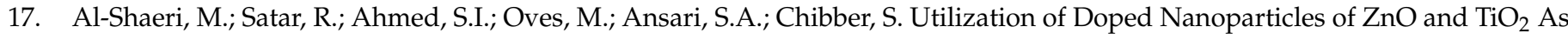
Antimicrobial Agent. Orient. J. Chem. 2019, 35, 1235. [CrossRef]

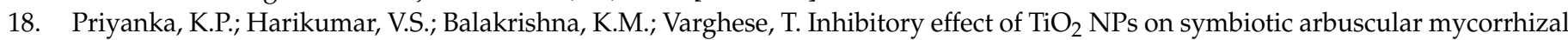
fungi in plant roots. IET Nanobiotechnol. 2017, 11, 66-70. [CrossRef]

19. de Dicastillo, C.L.; Correa, M.G.; Martínez, F.B.; Streitt, C.; Galotto, M.J. Antimicrobial effect of titanium dioxide nanoparticles. In Titanium Dioxide; IntechOpen: London, UK, 2020.

20. Papaioannou, W.; Gizani, S.; Haffajee, A.D.; Quirynen, M.; Mamai-Homata, E.; Papagiannoulis, L. The microbiota on different oral surfaces in healthy children. Oral Microbiol. Immunol. 2009, 24, 183-189. [CrossRef] [PubMed]

21. Vos, P.; Garrity, G.; Jones, D.; Krieg, N.R.; Ludwig, W.; Rainey, F.A.; Schleifer, K.-H.; Whitman, W.B. Bergey's Manual of Systematic Bacteriology: Volume 3: The Firmicutes; Springer Science \& Business Media: New York, NY, USA, 2011; Volume 3, ISBN 0387684891 
22. Ali, K.; Abul Qais, F.; Dwivedi, S.; Abdel-Salam, E.M.; Ansari, S.M.; Saquib, Q.; Faisal, M.; Al-Khedhairy, A.A.; Al-Shaeri, M.; Musarrat, J. Titanium dioxide nanoparticles preferentially bind in subdomains IB, IIA of HSA and minor groove of DNA. J. Biomol. Struct. Dyn. 2018, 36, 2530-2542. [CrossRef] [PubMed]

23. Saleem, S.; Ahmed, B.; Khan, M.S.; Al-Shaeri, M.; Musarrat, J. Inhibition of growth and biofilm formation of clinical bacterial isolates by $\mathrm{NiO}$ nanoparticles synthesized from Eucalyptus globulus plants. Microb. Pathog. 2017, 111, 375-387. [CrossRef] [PubMed]

24. Ahmed, B.; Syed, A.; Ali, K.; Elgorban, A.M.; Khan, A.; Lee, J.; AL-Shwaiman, H.A. Synthesis of gallotannin capped iron oxide nanoparticles and their broad spectrum biological applications. RSC Adv. 2021, 11, 9880-9893. [CrossRef]

25. Ahmed, B.; Solanki, B.; Zaidi, A.; Khan, M.S.; Musarrat, J. Bacterial toxicity of biomimetic green zinc oxide nanoantibiotic: Insights into ZnONP uptake and nanocolloid-bacteria interface. Toxicol. Res. 2019, 8, 246-261. [CrossRef] [PubMed]

26. Marsh, P.D.; Devine, D.A. How is the development of dental biofilms influenced by the host? J. Clin. Periodontol. 2011, 38, 28-35. [CrossRef]

27. Holsinger, F.C.; Bui, D.T. Anatomy, function, and evaluation of the salivary glands. In Salivary Gland Disorders; Springer: Berlin/Heidelberg, Germany, 2007; pp. 1-16.

28. Dawes, C. Estimates, from salivary analyses, of the turnover time of the oral mucosal epithelium in humans and the number of bacteria in an edentulous mouth. Arch. Oral Biol. 2003, 48, 329-336. [CrossRef]

29. Sarovich, D.S.; Price, E.P.; Von Schulze, A.T.; Cook, J.M.; Mayo, M.; Watson, L.M.; Richardson, L.; Seymour, M.L.; Tuanyok, A.; Engelthaler, D.M. Characterization of ceftazidime resistance mechanisms in clinical isolates of Burkholderia pseudomallei from Australia. PLoS ONE 2012, 7, e30789. [CrossRef] [PubMed]

30. Higashide, M.; Kuroda, M.; Omura, C.T.N.; Kumano, M.; Ohkawa, S.; Ichimura, S.; Ohta, T. Methicillin-resistant Staphylococcus saprophyticus isolates carrying staphylococcal cassette chromosome mec have emerged in urogenital tract infections. Antimicrob. Agents Chemother. 2008, 52, 2061-2068. [CrossRef]

31. Matthews, P.; Tomasz, A. Insertional inactivation of the mec gene in a transposon mutant of a methicillin-resistant clinical isolate of Staphylococcus aureus. Antimicrob. Agents Chemother. 1990, 34, 1777-1779. [CrossRef] [PubMed]

32. de Sousa, V.S.; da-Silva, A.P.d.S.; Sorenson, L.; Paschoal, R.P.; Rabello, R.F.; Campana, E.H.; Pinheiro, M.S.; dos Santos, L.O.F.; Martins, N.; Botelho, A.C.N. Staphylococcus saprophyticus recovered from humans, food, and recreational waters in Rio de Janeiro, Brazil. Int. J. Microbiol. 2017, 2017, 4287547. [CrossRef]

33. Kämpfer, P.; Arun, A.B.; Busse, H.-J.; Langer, S.; Young, C.-C.; Chen, W.-M.; Schumann, P.; Syed, A.A.; Rekha, P.D. Georgenia soli sp. nov., isolated from iron-ore-contaminated soil in India. Int. J. Syst. Evol. Microbiol. 2010, 60, 1027-1030. [CrossRef]

34. Becker, K.; Heilmann, C.; Peters, G. Coagulase-negative staphylococci. Clin. Microbiol. Rev. 2014, 27, 870-926. [CrossRef]

35. Coton, E.; Desmonts, M.H.; Leroy, S.; Coton, M.; Jamet, E.; Christieans, S.; Donnio, P.Y.; Lebert, I.; Talon, R. Biodiversity of Coagulase-Negative Staphylococci in French cheeses, dry fermented sausages, processing environments and clinical samples. Int. J. Food Microbiol. 2010. [CrossRef]

36. Basso, A.P.; Martins, P.D.; Nachtigall, G.; Sand, S.V.D.; Moura, T.M.; Frazzon, A.P.G. Antibiotic resistance and enterotoxin genes in Staphylococcus sp. isolates from polluted water in Southern Brazil. An. Acad. Bras. Cienc. 2014, 86, 1813-1820. [CrossRef] [PubMed]

37. Uttatree, S.; Charoenpanich, J. Purification and characterization of a harsh conditions-resistant protease from a new strain of Staphylococcus saprophyticus. Agric. Nat. Resour. 2018, 52, 16-23. [CrossRef]

38. Trivedi, M.K.; Branton, A.; Trivedi, D.; Nayak, G.; Mondal, S.C.; Jana, S. Antimicrobial sensitivity, biochemical characteristics and biotyping of Staphylococcus saprophyticus: An impact of biofield energy treatment. J. Women's Health Care 2015, 4, 1000271.

39. Doel, J.J.; Benjamin, N.; Hector, M.P.; Rogers, M.; Allaker, R.P. Evaluation of bacterial nitrate reduction in the human oral cavity. Eur. J. Oral Sci. 2005, 113, 14-19. [CrossRef]

40. Michels, F.; Colaert, J.; Gheysen, F.; Scheerlinck, T. Late prosthetic joint infection due to Rothia mucilaginosa. Acta Orthop. Belg. 2007, 73, 263.

41. Dhital, S.; Warren, F.J.; Butterworth, P.J.; Ellis, P.R.; Gidley, M.J. Mechanisms of starch digestion by $\alpha$-amylase-Structural basis for kinetic properties. Crit. Rev. Food Sci. Nutr. 2017, 57, 875-892. [CrossRef]

42. Woo, S.-G.; Cui, Y.; Kang, M.-S.; Jin, L.; Kim, K.K.; Lee, S.-T.; Lee, M.; Park, J. Georgenia daeguensis sp. nov., isolated from 4-chlorophenol enrichment culture. Int. J. Syst. Evol. Microbiol. 2012, 62, 1703-1709. [CrossRef]

43. Fulaz, S.; Devlin, H.; Vitale, S.; Quinn, L.; O'Gara, J.P.; Casey, E. Tailoring nanoparticle-biofilm interactions to increase the efficacy of antimicrobial agents against Staphylococcus aureus. Int. J. Nanomed. 2020, 15, 4779. [CrossRef]

44. Ameen, F.; Alshehri, W.A.; Nadhari, S. Al Effect of electroactive biofilm formation on acetic acid production in anaerobic sludge driven microbial electrosynthesis. ACS Sustain. Chem. Eng. 2019, 8, 311-318. [CrossRef]

45. Lee, J.H.; Kim, Y.G.; Cho, M.H.; Lee, J. ZnO nanoparticles inhibit Pseudomonas aeruginosa biofilm formation and virulence factor production. Microbiol. Res. 2014, 169, 888-896. [CrossRef] [PubMed]

46. Stepanović, S.; Ćirković, I.; Mijač, V.; Švabić-Vlahović, M. Influence of the incubation temperature, atmosphere and dynamic conditions on biofilm formation by Salmonella spp. Food Microbiol. 2003, 20, 339-343. [CrossRef]

47. Olson, E.R. Influence of $\mathrm{pH}$ on bacterial gene expression. Mol. Microbiol. 1993, 8, 5-14. [CrossRef]

48. Oliveira, R.; Melo, L.F.; Oliveira, A.; Salgueiro, R. Polysaccharide production and biofilm formation by Pseudomonas fluorescens: Effects of $\mathrm{pH}$ and surface material. Colloids Surf. B Biointerfaces 1994, 2, 41-46. [CrossRef] 
49. Rowland, B.M. Bacterial contamination of dental unit waterlines: What is your dentist spraying into your mouth? Clin. Microbiol. Newsl. 2003, 25, 73-77. [CrossRef]

50. Zhou, L.; Xia, S.; Zhang, Z.; Ye, B.; Xu, X.; Gu, Z.; Wang, X. Effects of pH, Temperature and Salinity on Extracellular Polymeric Substances of Pseudomonas aeruginosa Biofilm with N-(3-Oxooxtanoyl)-L-Homoserine Lactone Addition. J. Water Sustain. 2014, 4, 91.

51. Cai, T.; Ge, X.; Park, S.Y.; Li, Y. Comparison of Synechocystis sp. PCC6803 and Nannochloropsis salina for lipid production using artificial seawater and nutrients from anaerobic digestion effluent. Bioresour. Technol. 2013, 144, 255-260. [CrossRef]

52. Møretrø, T.; Hermansen, L.; Holck, A.L.; Sidhu, M.S.; Rudi, K.; Langsrud, S. Biofilm formation and the presence of the intercellular adhesion locus ica among staphylococci from food and food processing environments. Appl. Environ. Microbiol. 2003, 69, 5648-5655. [CrossRef] [PubMed]

53. Xu, H.; Zou, Y.; Lee, H.; Ahn, J. Effect of $\mathrm{NaCl}$ on the biofilm formation by foodborne pathogens. J. Food Sci. 2010, 75, M580-M585. [CrossRef]

54. Jensen, T.; Kelly, L.; Lazarides, A.; Schatz, G.C. Electrodynamics of noble metal nanoparticles and nanoparticle clusters. J. Clust. Sci. 1999, 10, 295-317. [CrossRef]

55. Linsebigler, A.L.; Lu, G.; Yates, J.T., Jr. Photocatalysis on $\mathrm{TiO}_{2}$ surfaces: Principles, mechanisms, and selected results. Chem. Rev. 1995, 95, 735-758. [CrossRef]

56. Battin, T.J.; Kammer, F.V.D.; Weilhartner, A.; Ottofuelling, S.; Hofmann, T. Nanostructured TiO2: Transport behavior and effects on aquatic microbial communities under environmental conditions. Environ. Sci. Technol. 2009, 43, 8098-8104. [CrossRef] [PubMed]

57. Sodagar, A.; Akhoundi, M.S.A.; Bahador, A.; Jalali, Y.F.; Behzadi, Z.; Elhaminejad, F.; Mirhashemi, A.H. Effect of TiO 2 nanoparticles incorporation on antibacterial properties and shear bond strength of dental composite used in Orthodontics. Dent. Press J. Orthod. $2017,22,67-74$. 